Journal of Biological Systems, Vol. 13, No. 4 (2005) 385-398

(C) World Scientific Publishing Company

\title{
THEORETICAL MORPHOSPACE AND ITS RELATION TO FRESHWATER GOMPHONEMOID-CYMBELLOID DIATOM (BACILLARIOPHYTA) LINEAGES
}

\author{
JANICE L. PAPPAS \\ Museum of Zoology, University of Michigan \\ 1109 Geddes Ave., Ann Arbor, MI 48109-1079, USA \\ jlpappas@umich.edu \\ Received 25 February 2005 \\ Revised 22 March 2005
}

\begin{abstract}
A number of basic forms in the gomphonemoid-cymbelloid diatom lineages were generated using three-dimensional (3D) parametric equations. The same boundary intervals and differentials for the parameters were used for all forms. From this, the absolute value of the Riemann sum of differences was determined for each variable between pairs of forms. The results were coordinate triplets, and they were plotted in 3D morphospace. Naviculoid forms occupied lower-valued morphospace in contrast to gomphonemoid and cymbelloid morphospaces. However, gomphonemoid and cymbelloid forms occupied different morphospaces. Forms representing Brebissonia occupied morphospace at the base of gomphonemoid forms, but occupied high-valued morphospace with respect to cymbelloid forms. Forms representing Encyonema had lower-valued coordinates compared to other cymbelloid forms. These results support hypotheses of Kociolek and Stoermer that state that naviculoid forms (and in particular, Placoneis) are ancestral to gomphonemoid and cymbelloid forms, Brebissonia is basal to gomphonemoid (but not cymbelloid) forms, and Encyonema is more primitive than other cymbelloid forms. This approach was useful in inferring the relation between theoretical morphospace and hypothesized phylogenies in the gomphonemoid-cymbelloid diatom lineages.
\end{abstract}

Keywords: Diatoms; Cymbelloid; Gomphonemoid; Naviculoid; Parametric Equations; Quadratic Surfaces; Theoretical Morphology.

\section{Introduction}

Diatoms have existed since at least the Jurassic, and were abundantly present in late Cretaceous and early Tertiary as well as in Turonian, Campanian and Maastrichtian deposits. ${ }^{1}$ This evolutionary record has proven to be a valuable resource in studies of paleoenvironments. With their siliceous cell walls, diatoms are some of the most striking geometric microorganisms in existence. The multitude of valve shapes is comprised of basic geometric forms or combinations thereof. Valve surface markings are also geometric shapes that comprise various patterns.

Size, geometry and shape are related features of any organism. ${ }^{2}$ Size includes measures of length, mass, surface area, and volume. One way to describe 3D 
geometry is in terms of a class of objects such as spheres, ellipsoids and cylinders. Shape indicates variation within a class of objects, such as the diameter of a cross-section of a spheroid and cylinder. ${ }^{2}$

The geometry of diatom morphology can be used to compare species that are phylogenetically related. This comparison can be used to theoretically infer how morphology evolves from one related species to another. Diatoms exhibit a wide variety of shapes and ornamentation on their surfaces that are amenable to quantification in relation to the geometric properties of their silica valves.

Diatoms have geometric characteristics in common that make analysis among their forms useful. However, diatom reproduction dictates that growth forms occur with changes in valve shape. During vegetative reproduction, size reduction occurs, and slight changes in shape are possible between parent and daughter cells. ${ }^{3,4}$ As cells get shorter, they become relatively wider. Once size reduction ceases because of developmental limitations, ${ }^{5-8}$ sexual reproduction occurs, and size restoration is accomplished via auxosporulation. ${ }^{9}$ Auxospore shape is somewhat dissimilar to the cell's shape during vegetative reproduction. Following the auxospore stage, an initial cell emerges which may also be unlike, but more similar to, vegetative cells. Once cell division commences vegetatively, the familiar diatom valve shape of the particular species becomes apparent..$^{10,11}$

\subsection{Applications of theoretical morphospace analysis}

Comparisons of theoretically-generated morphological phylogenies to actual phylogenies has been done. ${ }^{12,13}$ Raup $^{12}$ looked at the coiling geometry of mollusk and brachiopod shells as well as ammonoids. ${ }^{14}$ Based on Moseley's ${ }^{15}$ work, it was determined that a logarithmic spiral provides a simple growth model without change in shape during ontogeny. The actual shell forms are a subset of all the possible geometric forms. This four-dimensional space is based on the parameters of generating curve, whorl expansion rate, distance between generating curve and coiling axis, and the rate of whorl translation. The degree of overlap between successive whorls dictated which shell-form subspace is occupied. As such, only part of the total space encompasses actual forms.

Raup's ${ }^{12}$ study illustrates two important aspects of the geometry of morphology. First, a mathematical model can be devised to depict specimens' geometric forms. Second, actual specimens' geometry can be compared to all the possibilities of the geometric space defined by the mathematical model. However, Raup's ${ }^{12}$ model is useful only for forms where growth occurs without shape change. As has already been stated, this is not the case with diatoms.

Raup and Gould ${ }^{13}$ looked at morphological evolution as a stochastic process rather than as evidence of unidirectional selection. They compared simulated evolutionary trees with simulated morphologies. Incomplete filling of theoretical morphological space and unfolding of morphology or close correspondence between 
taxonomies based on phenetics and cladistics were some of the results of their simulations.

\subsection{Diatom phylogenies}

One group of diatoms that has been given a great deal of attention in terms of lineage includes the gomphonemoid-cymbelloid diatom lineages. ${ }^{16-22}$ This group includes Gomphonema, Gomphoneis, Cymbella, Encyonema, Gomphocymbella, and Didymosphenia. Morphological characters of specimens from these genera were used in cladistic analyses. In Kociolek and Stoermer, ${ }^{19}$ the results indicated that gomphonemoid and cymbelloid taxa are descendants of a Placoneis-like taxon having a naviculoid shape. Moreover, it was determined that Cymbella mexicana and Didymosphenia share a more recent common ancestor than either does with other Cymbella spp. sensu stricto or gomphonemoid taxa. ${ }^{19}$

In general, genetic or developmental factors are relative features that vary and change over evolutionary time. Phenotypic plasticity and innovation occur at varying rates for different organisms. ${ }^{2}$ To put it more succinctly, phylogenetic changes vary over evolutionary time. According to the fossil record, ${ }^{9,23,24}$ ancient centric diatoms had more complex ornamentation and were more highly silicified than modern taxa. Compared to centric diatoms, where the fossil record indicates their first appearance in the early Cretaceous ${ }^{1}$ pennate diatoms are relatively recent, with their first appearance indicated as the late Cretaceous. ${ }^{25}$ With the current trend of discovery of new genera, pennate diatoms may be undergoing a "floristic bloom" in a way similar to ancient taxa. Overall, diatoms on the whole have not changed dramatically within particular groups.

Specifically, after auxosporulation, initial cell shape for some gomphonemoid diatoms is apically and transapically symmetric, becoming transapically asymmetric during the vegetative life cycle. Additional alternative developmental pathways exist to produce apical symmetry. Change from transapical symmetry to apical symmetry is more complex and involves two developmental steps. After auxosporulation, apical symmetry changes to transapical symmetry of a "bent" initial cell. Subsequently, the cell changes its "bend" in a plane perpendicular to the plane of curvature of the cell. Alternatively, the initial cell may become "straightened." Cymbelloid apical asymmetry becomes more pronounced as size reduction occurs. ${ }^{4}$ The simpler change in apical symmetry is considered to be the more primitive characteristic within the gomphonemoid-cymbelloid lineages. ${ }^{19}$

In this study, we will be examining morphological differences among phylogenetically related taxa generated by mathematical functions. We will devise 3D shapes and surfaces that simulate naviculoid, gomphonemoid and cymbelloid taxa using parametric equations. We want to determine if these forms are mathematically related and determine how the proposed lineages from Kociolek and Stoermer ${ }^{19,21,22}$ are a subset of possible morphologically-generated space. In addition, we want to 
determine if naviculoid, and not cymbelloid, taxa are ancestral to gomphonemoid taxa using a theoretical morphological basis. Moreover, we will examine particular taxa and determine how their phylogenetic position is related to theoretical morphospace.

\subsection{Geometry of diatom forms}

Generally, diatom valve shapes may be modeled as quadratic surfaces. Some of the basic quadratic surfaces include the paraboloid, ellipsoid and hyperboloid, each of which is definable by an equation in $x, y$, and $z$. Diatom valve shapes may be viewed as deformations or combinations of these quadratic surfaces. A section cut out by a plane defined by two of the three axes that is normal to the valve surface represents that diatom's valve surface apically. A section cut out by a plane perpendicular to the valve surface represents a cross-section of the diatom transapically. Each coordinate plane used to cut out sections is defined by one of the variables with respect to the other two.

Quadratic surfaces can be defined by parametric equations. By using parameters, coordinates may be separated independently of one another to provide flexibility in controlling the shape of curves. Each curve for each coordinate (or variable) in a set of parametric equations is a function. In addition, direct transformations of the equations may be used. Although parametric representations are not unique, since more than one parameterization can be created for a given curve, they can be defined by a finitely bounded interval, and this can be held constant among a group of mathematically-generated diatoms for comparative purposes. This is especially useful when comparing phylogenetically related diatoms. Since similar diatom forms have evolved recurrently, they are not unique geometrically. Therefore, diatom valve geometries are not unique, and this is reflected in the use of parametric equations. ${ }^{26}$

Diatom valve surfaces are created as parameterized quadratic surfaces in this study. In particular, some of the basic forms used include the one-sheeted elliptic hyperboloid with a ruled surface and the hyperbolic paraboloid with a doubly ruled surface. The ruled surface depicts a straight line swept in space, while the doubly ruled surface depicts two families of lines that intersect that can be swept past each other in space. Surface variation by rotation and/or twisting of a ruled or doubly ruled quadratic surface allows for representation of valve pattern change among related forms. ${ }^{26}$

\section{Methods}

A form was defined by a set of parametric equations with parameters $t$ and $u$ in variables $x, y$, and $z$ to represent the basis from which to start. From the phylogenies used for study, the basal form represents the naviculoid shape. From this, changes in one or more of the three variables were made to induce the making of 
related phylogenetic forms, namely, cymbelloid and gomphonemoid shapes. While changes were made in the variables, the parameters and their respective differentials were held constant. That is, the generalized set of parametric equations used as a basis is:

$$
\begin{aligned}
& x=k \sin \left(\frac{t}{2}\right)+[\text { function }] \\
& y=\sec h(m t) \tanh (10 u)+[\text { function }] \\
& z=[\mathrm{TRIG}]\left(\frac{t}{2}\right)
\end{aligned}
$$

where $k$ is an integer, $0<m<1.5$, [function] is one or more hyperbolic or trigonometric functions, and [TRIG] is sine, cosine, or tangent. The parameters were defined on the same interval for all forms, and the differential for each parameter remained the same for all forms as well. They are defined as:

$$
t=(-\pi, \pi), \quad d t=\frac{\pi}{16}
$$

and

$$
u=(-2 \pi, 2 \pi), \quad d u=\frac{\pi}{8} .
$$

From each form's associated parametric equations, comparisons were made between forms from variable to variable. The $x$-function from one form was compared to the $x$-function for another form. The $y$ - and $z$-functions were compared as well. These comparisons were calculated to be the absolute value of the area between curves, as a Riemann sum, and given by the generalized definite integral:

$$
A=\mid \int_{t, u} \operatorname{var}_{i}-\operatorname{var}_{j}[\text { differential }] \mid
$$

where $\operatorname{var}_{i}$ and $\operatorname{var}_{j}$ represent the same variable of functions for two different forms, $i$ and $j$, with parameters $t$ and $u$ evaluated at the same boundary intervals throughout as specified above. Each comparison yielded a numerical coordinate triplet.

Using the triplets in a matrix, a 3D plot was created of all the comparisons. The plotted space represents overlapping regions between forms, and therefore the total space occupied is a subset of the total possible morphospace for these forms. This morphospace was evaluated with respect to proposed phylogenies determined by cladistic analysis.

\section{Results}

From the generalized set of parametric equations, three naviculoid, ten gomphonemoid, one gomphocymbelloid, and three cymbelloid forms were created. An example of a naviculoid form (Fig. 1) was devised with the following parametric 


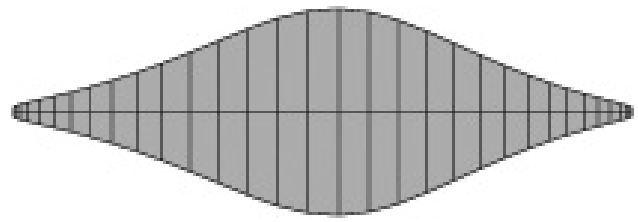

Fig. 1. Naviculoid form.

equations:

$$
\begin{aligned}
& x=3 \sin \left(\frac{t}{2}\right) \\
& y=\sec h(1.2 t) \tanh (10 u) \\
& z=\sin \left(\frac{t}{2}\right) .
\end{aligned}
$$

For an exemplary gomphonemoid form (Fig. 2), one set was:

$$
\begin{aligned}
& x=3 \sin \left(\frac{t}{2}\right)-\sec h\left(t^{2}\right) \\
& y=\sec h(1.2 t) \tanh (10 u) \\
& z=\sin \left(\frac{t}{2}\right) .
\end{aligned}
$$

The gomphocymbelloid form (Fig. 3) devised was:

$$
\begin{aligned}
& x=4 \sin \left(\frac{t}{2}\right)-\cos \left(\frac{t}{2}\right) \\
& y=\sec h(1.2 t) \tanh (10 u)-\sec h\left(\frac{t}{4}\right) \\
& z=\sin \left(\frac{t}{2}\right) .
\end{aligned}
$$

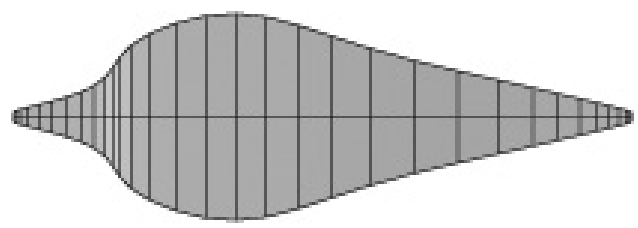

Fig. 2. Gomphonemoid form.

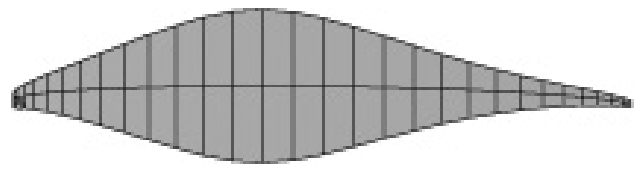

Fig. 3. Gomphocymbella form. 


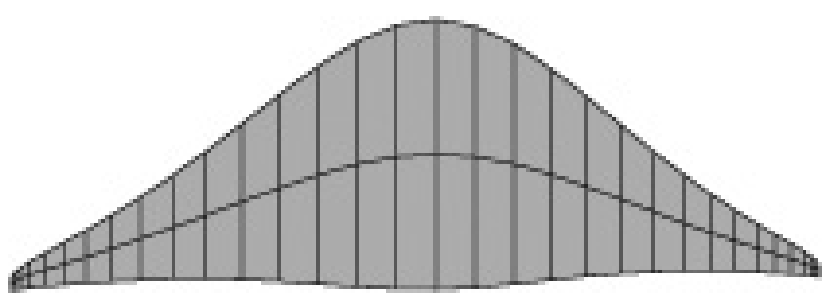

Fig. 4. Encyonema form.

An example of a cymbelloid form (Fig. 4) was:

$$
\begin{aligned}
& x=3 \sin \left(\frac{t}{2}\right) \\
& y=\sec h(1.2 t) \tanh (10 u)-\sec h(t) \\
& z=\sin \left(\frac{t}{2}\right) .
\end{aligned}
$$

In all cases, $t=(-\pi, \pi), d t=\frac{\pi}{16}, u=(-2 \pi, 2 \pi)$, and $d u=\frac{\pi}{8}$.

The absolute value of the area between curves was calculated between variables in a pairwise fashion, and the resultant coordinate triplets for each comparison were combined in a matrix and plotted (Fig. 5). Each variable is an equation of a function of one or both parameters. Finding the area between the same functions for the two forms is the same as finding the sum of the differences between forms with respect to one function. That is, if the result is zero, the two forms are the same with respect to that function. If the result is greater or less than zero, the forms are different with respect to that function. For plotting purposes, the absolute value of the sum of the differences was used. In Fig. 5, the order of sections plotted in morphospace is determined by numerical solution of Eq. (2.6) as given in the matrix of triplets. A total of 85 pairwise comparisons were made.

Each axis was defined in the $3 \mathrm{D}$ plot of all triplets. The definition was determined by the change in shape of the basic naviculoid form per axis. Changes in the $x$-variable function yielded translation of apical symmetry to asymmetry for the $x$-axis. Therefore, this axis was designated the degree of clavateness (or hastateness) or apical symmetry and transapical asymmetry. Changes in the $y$-variable function produced "bending" of the form transapically. Therefore, the $y$-axis was designated degree of crescenticness (or semicircularity) or transapical symmetry and apical asymmetry. The $z$-axis did not change with respect to the $z$-variable function. Therefore, this axis represented degree of linearity (or lanceolateness) or apical and transapical symmetry.

Specific results with regard to particular axes are compiled in Table 1. Note that apically symmetric forms were defined on the $z$ - and $x$-axes versus gomphocymbelloid forms, which were defined on the $y$-axis. However, when the comparison was made with transapically symmetric forms, gomphocymbelloid forms defined the $x$-axis. 


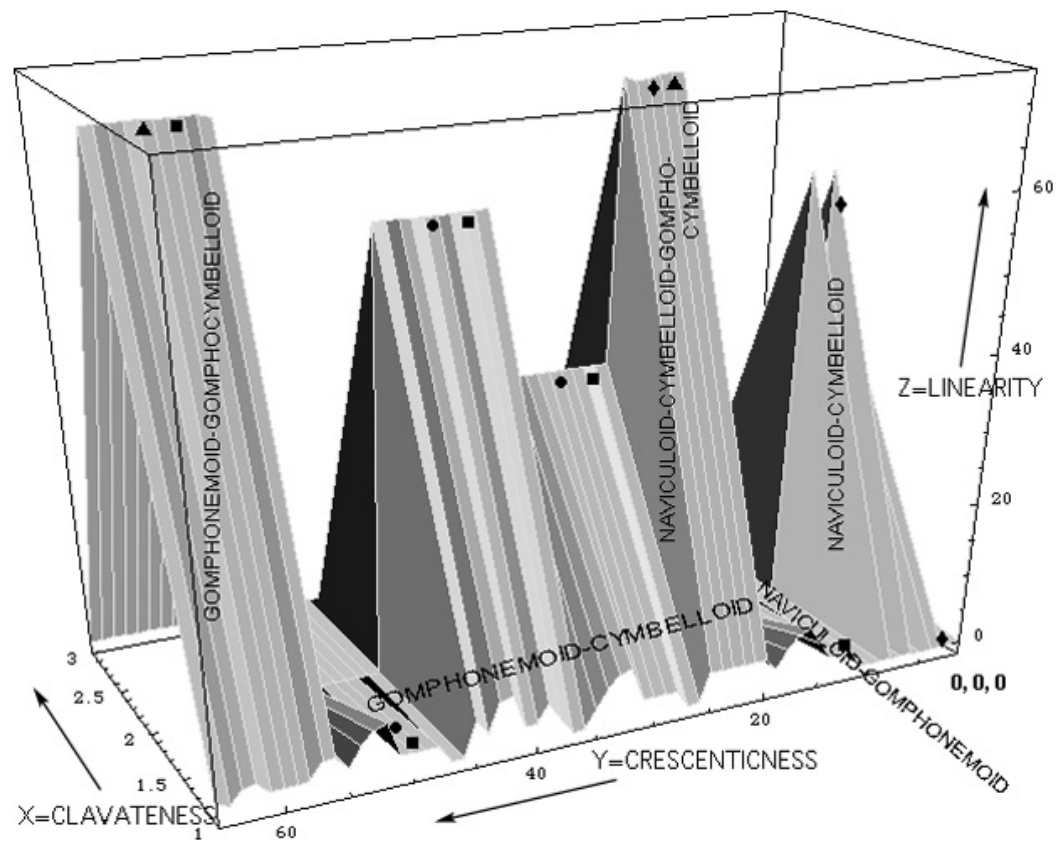

Fig. 5. Plot of all coordinate triplets from the absolute value of the sum of the differences between variables for each pair of forms. Combinations of forms are labeled. Individual taxon forms labeled as: $\bullet=$ Brebissonia, $\bullet=$ Encyonema, $\mathbf{\Delta}=$ Gomphocymbella, $\mathbf{\square}=$ Gomphoneis.

Table 1. Comparison of forms and axes defined for Fig. 5.

\begin{tabular}{lcc}
\hline \multicolumn{1}{c}{ Forms paired } & 1st form's axis defined & 2nd form's axis defined \\
\hline Naviculoid-cymbelloid & $z$ & $y$ \\
Naviculoid-gomphonemoid & $z$ & $x$ \\
Naviculoid-gomphocymbelloid & $z$ & $y$ \\
Cymbelloid-gomphonemoid & $y$ & $x$ \\
Cymbelloid-gomphocymbelloid & $y$ & $x$ \\
Gomphonemoid-gomphocymbelloid & $y$ & $x$ \\
\hline
\end{tabular}

In Fig. 5, most of the combined morphospace occurs at the bottom where the forms are most similar. Then, the morphospace decreases as movement is away from the origin and as the differences in forms are mapped. Each section representing comparison of forms is shown in the morphospace plotted. Naviculoid forms, when compared to all others, occupy the first approximate third of the plot closest to the origin. Next, the gomphonemoid-cymbelloid forms occupy most of the remaining morphospace. At the very end, the gomphonemoid-gomphocymbelloid section occupies the region farthest from the origin.

A number of particular forms are indicated in 3D morphospace (Fig. 5). Brebissonia (Fig. 6), Encyonema (Fig. 4), Cymbella 1 (Fig. 7), Cymbella 2 (Fig. 8), 


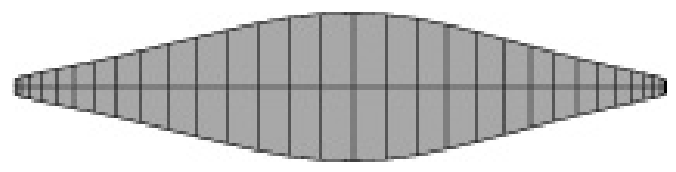

Fig. 6. Brebissonia form.

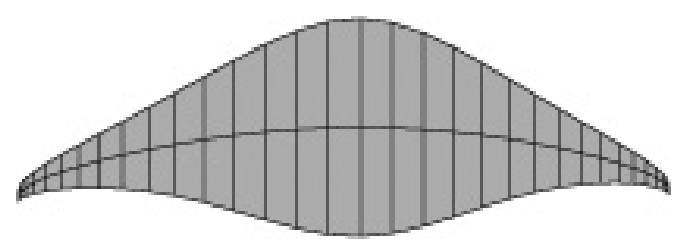

Fig. 7. Cymbella 1 form.

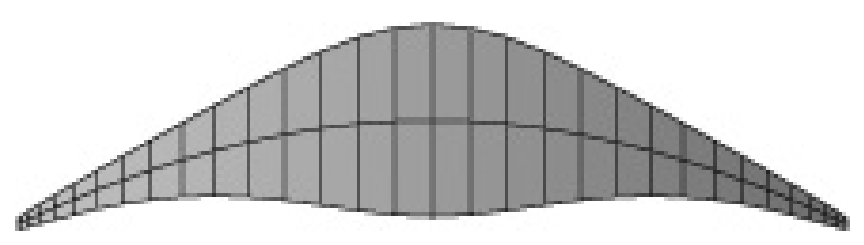

Fig. 8. Cymbella 2 form.

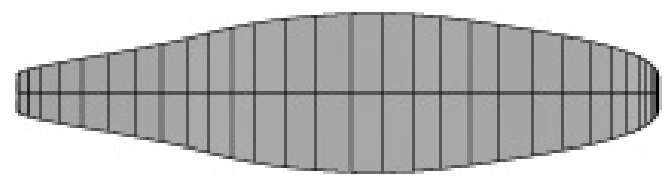

Fig. 9. A Gomphoneis form.

Gomphocymbella (Fig. 3), and a variety of Gomphoneis (Fig. 9) forms are plotted using their coordinates. Brebissonia occurs close to the origin with respect to Cymbella 2, but distant with respect to Cymbella 1 and Encyonema. Encyonema and Cymbella 1 are more distant with respect to gomphonemoid forms than is Cymbella 2. Gomphocymbella is distant from all other forms in combined morphospace, but similar to particular gomphonemoid and cymbelloid forms. Some forms of Gomphoneis are more similar to Cymbella 2 and others are more similar to Cymbella 1 and Encyonema.

For some of the forms used in this study, Persistence of Vision Ray Tracer (POVRay Tracer) $3.5^{27}$ was used to create $3 \mathrm{D}$ images. A composite of these images is depicted in Fig. 10. 


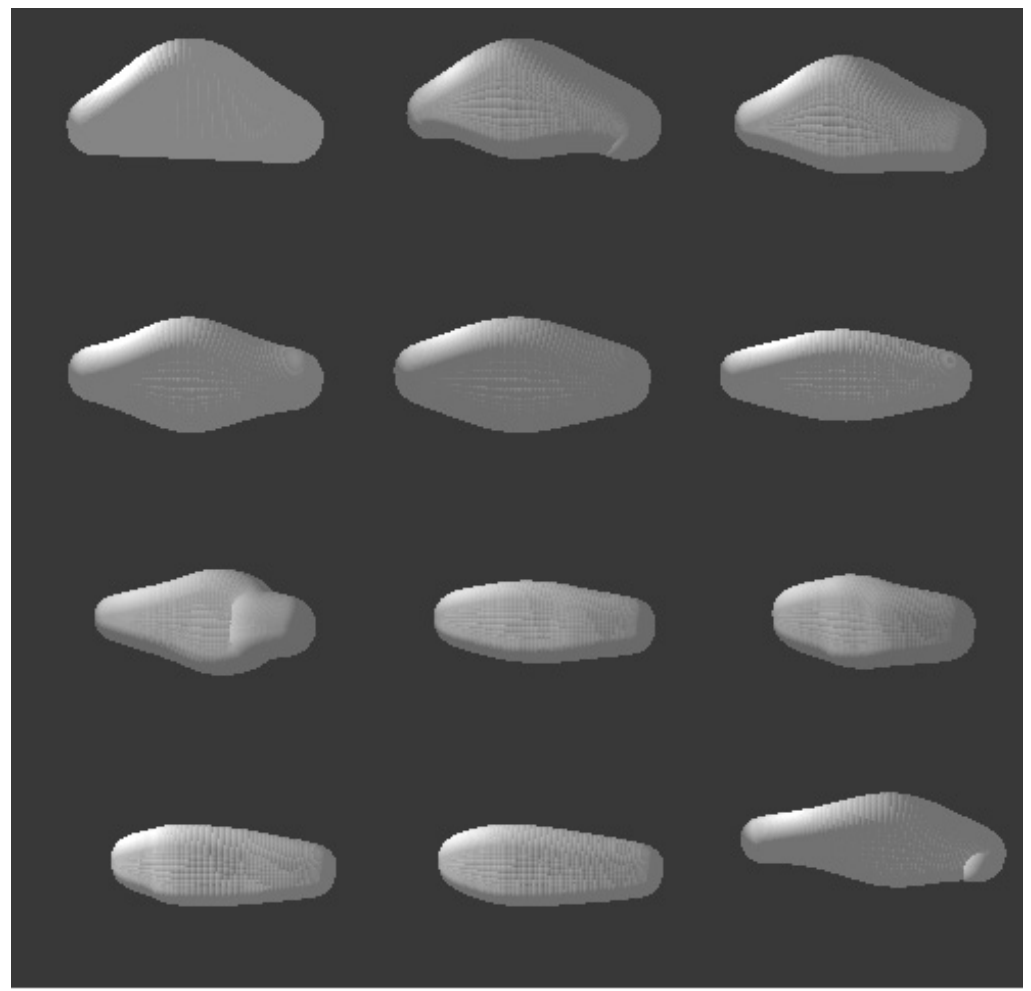

Fig. 10. Composite of 12 POV-Ray Tracer 3.5 generated diatom forms. First row (top): Encyonema, Cymbella 1, and Cymbella 2. Second row (from top): naviculoid 1, naviculoid 2, and Brebissonia. Third row (from top): gomphonemoid 1, Gomphoneis 1, and Gomphoneis 2. Fourth row (bottom): gomphonemoid 2, gomphonemoid 3, and Gomphocymbella.

\section{Discussion}

We used 3D parametric equations to create theoretical morphological forms depicted in gomphonemoid-cymbelloid diatom lineages. This approach provided a preliminary glimpse into one way to adapt mathematically-derived morphologies to hypothesized phylogenies.

The filiation of diatoms to chrysophytes, dictyochophytes, and synurophytes is still a matter of debate. ${ }^{28}$ In general, questions surround issues involving, but not limited to, differences in cytology, physiology, and ontogeny. Unlike radiolarians, ebridian dinoflagellates, and silicoflagellates, diatoms do not have a latticework skeleton. ${ }^{29}$ They have much more complex and diverse external valve surface patterns and shapes. ${ }^{30}$ Because of this, they cannot be represented simply by a series of rods and plates. In addition, the fact that diatoms get smaller as they get older and change slightly in shape during the process makes it difficult to apply previously tried theoretical morphological techniques based on growth models. ${ }^{31}$ 
Diatoms may exhibit similarity to microorganisms with a siliceous latticework in that they may exhibit minimization of apical surface area and silica conservation since it is more economical to produce silica frustules in this way. ${ }^{4}$ However, silica conservation and economy in frustule morphogenesis must be tempered with evidence that marine diatoms have less silica than freshwater diatoms. ${ }^{32}$

Another problem in applying previously tried theoretical morphological techniques to diatoms is measurements of volume. Within a given species, silica content can vary within a narrow range. However, biovolume estimates can vary greatly. For example, Aulacoseira granulata has biovolume estimates of $283^{32}$ to over $5100 \mu \mathrm{m}^{3}{ }^{30}$ Theoretical morphological studies involving surface area and volume measurements ${ }^{12,29}$ cannot be applied as easily to diatoms.

In this study, we used a different approach to discern the relation between theoretical morphospace and hypothesized phylogenies of gomphonemoid-cymbelloid lineages. That is, we used an approach that gives a general view of possible relations among naviculoid, cymbelloid, and gomphonemoid forms in morphospace and how this relates to hypothesized phylogenies. The results indicate that some of the hypotheses in Kociolek and Stoermer ${ }^{19,21,22}$ are supported.

For Kociolek and Stoermer, ${ }^{19}$ Placoneis is considered to be basal to cymbelloid and gomphonemoid taxa. This is generally supported by the results depicted in Fig. 5 whereby naviculoid morphospace is at the confluence of the origin of the $x-, y-$, and $z$-axes. Still to be determined is specifically where a mathematicallygenerated Placoneis-like form would be plotted in the naviculoid morphospace. Gomphonemoid and cymbelloid forms occupy different morphospaces.

Brebissonia is distant from cymbelloid forms since its coordinates are at high-valued cymbelloid morphospace. With regard to Brebissonia, cymbelloid and gomphonemoid occupy different regions of morphospace, lending support to the hypothesis in Kociolek and Stoermer ${ }^{19}$ that cymbelloid taxa are not ancestral to gomphonemoid taxa. Brebissonia coordinates are basal to gomphonemoid forms in terms of apical symmetry. In particular, Brebissonia occupies low-valued morphospace in contrast to Gomphoneis or Gomphocymbella. This supports the hypothesis in Kociolek and Stoermer ${ }^{19}$ that Brebissonia is more primitive than gomphonemoid taxa.

In naviculoid-cymbelloid morphospace, Encyonema coordinates appear prior to other cymbelloid forms along the $y$-axis. This supports the hypothesis that Encyonema is more primitive than other cymbelloid forms. ${ }^{19}$ Development of additional tests between Encyonema and a cymbelloid form such as Reimeria would be interesting with regard to determining which of these is more primitive. Kociolek and Stoermer ${ }^{19}$ hypothesized Reimeria to be more primitive than Encyonema, while Krammer and Lange-Bertalot ${ }^{33}$ and $\mathrm{Cox}^{34}$ hypothesized Reimeria to be more closely related to gomphonemoid diatoms.

The position of Gomphoneis is less clear with respect to other gomphonemoid forms in morphospace. In gomphonemoid-gomphocymbelloid morphospace, 
Gomphoneis occurs close to Gomphocymbella. This may reflect the proximal distance of the two taxa in Kociolek and Stoermer's ${ }^{17}$ cladistic analysis. Gomphocymbella is also different from other gomphonemoid forms and more similar to some cymbelloid forms. This supports the findings of Kociolek and Stoermer ${ }^{19,20}$ where Gomphocymbella ancyli was found to be more closely allied to cymbelloid taxa. Cantonati and Angeli ${ }^{35}$ and Krammer $^{36}$ support the view that Gomphocymbella ancyli is more closely related to Cymbella, as described in their studies of this taxon renamed as Cymbella ancyli and Gomphocymbellopsis ancyli, respectively. An East African Gomphocymbella, Gomphonema, and some Gomphoneis were found to have the same ancestral form. ${ }^{21,22}$ East African gomphocymbelloid taxa more closely related to Gomphonema are now placed in the genus Afrocymbella. ${ }^{36}$

Within the gomphonemoid-cymbelloid morphospace, a mixed picture emerges for Gomphoneis. With regard to Encyonema and Cymbella 1, Gomphoneis is similarly high-valued, indicating difference from basal gomphonemoid forms. However, in the same morphospace, Gomphoneis with respect to Cymbella 2 occupies lowvalued space, and this indicates that Gomphoneis is also basal with regard to some gomphonemoid forms. In naviculoid-gomphonemoid morphospace, Gomphoneis is neither basal nor high-valued. A separate analysis of gomphonemoid forms using many members may be necessary to more fully evaluate these results. According to Kociolek and Stoermer, ${ }^{19,21,22}$ the positions of Gomphocymbella, Gomphonema, and Gomphoneis in phylogenetic analyses are unresolved and that these genera are not monophyletic.

In taxonomic and classification studies, diatom valve symmetry has been used as a primary character for consideration. According to Kociolek and Stoermer, ${ }^{19}$ relying on symmetry may not be the best way to discern lineages. This study supports the contention that valve symmetry is not easily used as a differentiating character given the plot of coordinates of forms in morphospace (Fig. 5).

We have compared hypothesized phylogenetic positions to coordinates within theoretical naviculoid-cymbelloid-gomphonemoid morphospace. Although this is not a direct mapping of the cladogram into morphospace, ${ }^{37}$ this approach is useful in a similar way since points can be specified in the morphospace and lineages may be inferred and superimposed.

\section{Acknowledgments}

We would like to thank Karl Niklas and two anonymous reviewers for suggestions that were useful in improving this manuscript.

\section{References}

1. Strelnikova NI, Diatoms of the Cretaceous period, Nova Hedwigia 53:311-321, 1975.

2. Niklas KJ, The Evolutionary Biology of Plants, University of Chicago Press, Chicago, 1997. 
3. Mann DG, An ontogenetic approach to diatom systematics, in Mann DG (ed.), Proceedings of the Seventh International Diatom Symposium, O. Koeltz, Koenigstein, pp. 113-141, 1984.

4. Mann DG, The origins of shape and form in diatoms: the interplay between morphogenetic studies and systematics, in Ingram DS, Hudson AJ (eds.), Shape and Form in Plants and Fungi, Academic Press, London, 17-38, 1994.

5. Edlund MB, Stoermer EF, Ecological, evolutionary, and systematic significance of diatom life histories, J Phycol 33:897-918, 1997.

6. MacDonald JD, On the structure of the diatomaceous frustule, and its genetic cycle, Ann Mag Nat Hist 4,3:1-8, 1869.

7. Pfitzer E, Über den bau and zellteilung der diatomeen, Bot Z 27:774-776, 1869.

8. Pfitzer E, Untersuchungen über bau and entwicklung der bacillariaceen (diatomeen), Bot Abh Geb Morphol Physiol 1:1-189, 1871.

9. Round FE, Crawford RM, Mann DG, The Diatoms. Biology and Morphology of the Genera, Cambridge University Press, Cambridge, 1990.

10. Schmid A-MM, III2, Morphogenetic forces in diatom cell wall formation, in Bereiter-Hahn J, Anderson OR, Reif W-E (eds.), Cytomechanics, Springer, Berlin, pp. 183-199, 1987.

11. Schmid A-MM, Aspects of morphogenesis and function of diatom cell walls with implications for taxonomy, Protoplasma 181:43-60, 1994.

12. Raup DM, Geometric analysis of shell coiling: general problems, J Paleontol 40:11781190, 1966.

13. Raup DM, Gould SJ, Stochastic simulation and evolution of morphology - towards a nomothetic paleontology, Syst Zool 23:305-322, 1974.

14. Raup DM, Chamberlain, Jr. JA, Equations for volume and center of gravity in ammonoid shells, J Paleontol 41:566-574, 1967.

15. Moseley H, On the geometrical forms of turbinated and discoid shells, $R$ Soc Lond Philos Trans 128:351-370, 1838.

16. Kociolek JP, Stoermer EF, On the taxonomy and ultrastructure of the fossil diatom Gomphoneis cantalica, Cryptogam, Algol 7:1-8, 1986.

17. Kociolek JP, Stoermer EF, A consideration of the ultrastructure of Cymbella sinuata and its allies, and their transfer to Reimeria, gen. Nov., Syst Bot 12:451-459, 1987 a.

18. Kociolek JP, Stoermer EF, Geographic range and variability of the diatom (Bacillariophyceae) Gomphonema ventricosum Greg., Nova Hedwigia 45:223-236, 1987b.

19. Kociolek JP, Stoermer EF, A preliminary investigation of the phylogenetic relationships among the freshwater, apical pore field-bearing cymbelloid and gomphonemoid diatoms (Bacillariophyceae), J Phycol 24:377-385, 1988.

20. Kociolek JP, Stoermer EF, Taxonomy and ultrastructure of some Gomphonema and Gomphoneis taxa from the upper Laurentian Great Lakes, Can J Bot 69:1557-1576, 1991.

21. Kociolek JP, Stoermer EF, Freshwater gomphonemoid diatom phylogeny: preliminary results, Hydrobiologia 269/270:31-38, 1993a.

22. Kociolek JP, Stoermer EF, The diatom genus Gomphocymbella O. Müller: taxonomy, ultrastructure and phylogenetic relationships, Nova Hedwigia 106:71-92, 1993b.

23. Gersonde R, Harwood DM, Lower Cretaceous diatoms from ODP Leg 113 Site 693 (Weddell Sea). Part 1: vegetative cells, in Barker PF, Kennett JP, et al. (eds.), Proceedings of the Ocean Drilling Program, Scientific Results, Vol. 113, College Station, Texas, pp. 365-402, 1990. 
24. Harwood DM, Gersonde R, Lower Cretaceous diatoms from ODP Leg 113 Site 693 (Weddell Sea). Part 2: resting spores, chrysophycean cysts, an endoskeletal dinoflagellate, and notes on the origin of diatoms, in Barker PF, Kennett JP et al. (eds.), Proceedings of the Ocean Drilling Program, Scientific Results, Vol. 113, College Station, Texas, pp. 403-425, 1990.

25. Graham LE, Wilcox LW, Algae, Prentice Hall, NJ, 2000.

26. Pappas JL, Geometry and topology of diatom shape and surface morphogenesis for use in applications of nanotechnology, J Nanosci Nanotechnol 5:120-130, 2005.

27. Persistence of Vision Ray Tracer 3.5, POV-Ray Team (Persistence of Vision Raytracer Pty. Ltd., 2002). http://www.povray.org/.

28. Blackwell WH, Powell MJ, A review of group filiation of strameopiles, additional approaches to the question, Evol. Theory 12:49-88, 2000.

29. McCartney K, Loper DE, Optimized skeletal morphologies of silicoflagellate genera Dictyocha and Distephanus, Paleobiology 15:283-298, 1989.

30. Sicko-Goad LM, Schelske CL, Stoermer EF, Estimation of intracellular carbon and silica content of diatoms from natural assemblages using morphometric techniques, Limnol Oceanogr 29:1170-1178, 1984.

31. Thomas RDK, Shearman RM, Stewart GW, Evolutionary exploitation of design options by the first animals with hard skeletons, Science 288:1239-1242, 2000.

32. Conley DJ, Kilham SS, Theriot E, Differences in silica content between marine and freshwater diatoms, Limnol Oceanogr 34:205-213, 1989.

33. Krammer K, Lange-Bertalot H, Bacillariophyceae. 1. Teil: Naviculaceae, in Ettl H, Gerloff J, Heynig H, Mollenhauer D (eds.), Süßwasserflora von Mitteleuropa, Band 2/1, Gustav Fischer Verlag, Stuttgart, Jena, Germany, 1986.

34. Cox EJ, Taxonomy of diatoms: a fascination with minutiae, in Norton TA (ed.), Out of the Past Collected Reviews to Celebrate the Jubilee of the British Phycological Society, The British Phycological Society, Belfast, pp. 49-67, 2003.

35. Cantonati M, Angeli N, New findings on the ecology and ultrastructure of Cymbella ancyli Cleve, Diatom Res 18:377-384, 2003.

36. Krammer K, Diatoms of Europe, Vol. 4. Cymbopleura, Delicata, Navicymbula, Gomphocymbellopsis, Afrocymbella. A. R. G. Gantner Verlag K. G., Ruggell, Liechtenstein, 2003.

37. Stone JR, Mapping cladograms into morphospaces, Acta Zool 84:63-68, 2003. 